\title{
ALIHFUNGSI LAHAN MENGUBAH WAJAH DESA
}

\author{
Joanes Babtista Joan Gerald Noveriano Leonis \\ Universitas Gadjah Mada \\ geraldleonis7@gmail.com
}

\begin{abstract}
Village is an important social unit in the living space that also experiences its dynamics. In contrast to cities, villages give us perspective on value and historical construction. With the development and uncontrolled population explosion also has an impact on the changing face of the village. The crowded city forced the population to migrate to find land in the village. This study aims to interpret changes in the face of the village as a result of urban migration. This study uses qualitative methods with a case study approach. Data collection is done by interviews, observation and document study. This study took respondents from the initial community, migrants (city residents) who built residential in the village, as well as village apparatus. Based on the results of the study, there were a variety of impacts that occurred as a result of the migration of city residents to villages. Different residential buildings, better economic stability signal that there will be social inequality in the village, and this gives an impulse for social decohesiveness.
\end{abstract}

\section{Keyword: changes, social deohesiveness, village}

\begin{abstract}
Abstraksi. Desa merupakan suatu unit sosial penting dalam ruang hidup yang juga mengalami dinamikanya. Berbeda dengan kota, desa memberikan kita perpsektif tentang konstruksi nilai dan historis. Dengan perkembangan serta ledakan penduduk yang tidak terkontrol berdampak pula pada perubahan wajah desa. Kota yang padat memaksa penduduknya bermigrasi mencari lahan di desa. Penelitian ini bertujuan untuk memaknai perubahan wajah desa akibat dari migrasi penduduk kota. Penelitian ini menggunakan metode kualitatif dengan pendekatan studi kasus. Pengumpulan data dilakukan dengan wawancara, observasi dan studi dokumen. Penelitian ini mengambil responden dari masyarakat awal, pendatang (penduduk kota) yang membangun hunian di desa, serta aparatur desa. Berdasarkan hasil penelitian, ada beragam dampak yang terjadi akibat dari migrasi penduduk kota ke desa. Bangunan hunian yang berbeda, kemapanan ekonomi yang lebih baik memberikan signal akan terjadi kesenjangan sosial di desa, dan hal ini memberikan impuls terjadinya dekohesivitas sosial.
\end{abstract}

\section{Kata kunci: desa, dekohesivitas sosial, perubahan}

\section{PENDAHULUAN}

Desa merupakan sebuah unit sosial yang unik dan sarat nilai. Di samping eksistensinya yang penuh makna, desa merupakan wilayah paling strategis menjadi tujuan tumbuhan pemukiman baru. Karakteristik lain dari desa adalah sebuah komunitas kecil yang terikat pada lokalitas tertentu baik sebagai tempat tinggal dan juga dalam kebutuhan hidup masyarakat desa bergantung kepada pertanian (Rahardjo, 2010:28). Desa yang terletak pada daerah pinggiran kota, kerap menjadi destinasi paling potensial menjadi tempat pertumbuhan pemukiman baru. Kondisi ini merupakan bagian dari alternatif ketika penduduk kota jenuh dengan kepadatan dan nilai jual tanah yang 
tinggi di kota. Ketimpangan tersebut tidak serta merta terlihat dari segi sosial, budaya, ekonomi ataupun politik. Ketimpangan spasial menstimulasi penduduk kota berpindah mencari lahan pemukiman baru. Mesti diakui bahwa ketersediaan lahan di kota tidak sebanyak desa, harga jual lahan pun melonjak dikarenakan permintaan yang tinggi. Hal yang sama dialami penduduk Kabupaten Ende Provinsi Nusa Tenggara Timur (NTT). Dengan sempitnya luas lahan dalam kota dengan tingkat kepadatan tinggi memaksa penduduk untuk memikir kembali membangun hunian di dalam kota. Upaya mencari lahan untuk pemukiman baru bergerak menuju wilayah pinggiran. Salah satu wilayah pinggiran yang paling strategis adalah Desa Nanganesa.

Ada empat (4) hal yang menjadikan Desa Nanganesa menjadi daerah yang banyak diminati penduduk kota Ende. Pertama, jarak antara Desa Nanganesa dan pusat kota Ende hanya berkisar 5 (lima) $\mathrm{km}$. Hal ini tentu menjadi pilihan yang tepat bagi para penduduk yang bekerja di Kota. Jangkauan untuk mencapai kota tidak jauh sehingga mudah untuk menjadi commuter. Kedua, affordability. Rata-rata nilai jual lahan di Desa Nanganesa murah. Yang lebih menarik adalah penduduk kota yang membeli lahan di Desa Nanganesa tidak hanya mereka yang memiliki latar belakang sebagai Aparatur Sipil Negara (ASN), namun ada pula pemilik modal besar seperti pengusaha, kontraktor dan pemilik toko besar di kota. Ketiga, availability atau ketersediaan. Desa Nanganesa memiliki ketersediaan lahan yang luas dan banyak. Bahkan lahan pertanian dan perkebunan yang selama ini dijadikan modal mencari nafkah pun rela dijual. Keempat, Acceptbility atau keterimaan. Para penduduk setempat memiliki kultur yang baik, berelasi sosial dengan mudahnya dan sangat welcome terhadap penduduk baru.

Dari keempat aspek di atas, dapat dilihat bahwa Desa Nanganesa menawarkan kenyamanan yang layak untuk dijadikan pemukiman baru bagi penduduk kota. Desa Nanganesa yang unik sebenarnya sedang menghadapi gejala perubahan yang besar. Daerah pinggiran kota terutama kerapkali merupakan daerah yang rentan bencana dan minim perencanaan dan integrasi secara institusi yang biasa diterjemahkan dalam perkembangan yang merata karena adanya fragementasi lahan dan kehidupan sosial yang lebih eksklusif. Sadar atau tidak, Desa Nanganesa sedang mengalami lonjakan dinamika di setiap sendi hidupnya. Lihat saja, proyeksi sosial yang dibawa oleh pemukim baru, berpotensi menggeser pola hidup sosial dari kebersamaan menjadi lebih individualistik. Kemapanan ekonomi yang jomplang dapat mengurai dan menganggu kerekatan sosial dan budaya. Akan ada lack, dimana keterikatan dan kepatuhan akan nilai budaya akhirnya luntur sedikit demi sedikit. Kalau tidak diperhatikan dengan seksama, penulis memprediksi tidak akan lama lagi kekhasan dan kematangan nilai desa akan segera pudar. Seluruhnya diganti dengan wajah kota yang cepat, taktis dan sangat terikat dengan waktu dan kerja.

Akselerasi yang dialami Desa sedikit mengusik kenyamanan dan berbagai keharmonisan desa. Tak pelak hal ini dapat memberikan kekhawatiran bagi masyarakat setempat. Apalagi di satu sisi, dampak penjualan tanah ini melahirkan 
kepentingan ekonomi yang memaksa masyarakat untuk reaktif dan adaptif.

Masyarakat mesti segera memaknai perubahan ini dengan cepat. Transformasi fisik dan lingkungan akibat alihfungsi lahan mengikis sekat ekonomi sosial yang telah hidup. Hal ini tidak terlepas dari kebutuhan. Masyarakat Desa Nanganesa terjebak dalam arus ekonomi dan di sisi lainnya permintaan akan lahan yang tinggi semakin menstimulasi masyarakat menjual lahan mereka.

Pada dasarnya penelitian ini bertujuan untuk melihat dampak alihfungsi lahan akibat dari masifnya migrasi pembelian tanah oleh penduduk kota Ende. Meskipun di lain pihak, masyarakat memiliki motif rasional dalam mempertimbangkan penjualan lahan yan dimilikinya. Terlebih signifikansi locus Desa Nanganesa yang berada tepat di pinggiran kota Ende mampu menjadi model penelitian guna mempelajari bagaimana masifnya perkembangan perubahan daerah pinggiran menuju wajah kekotaan.

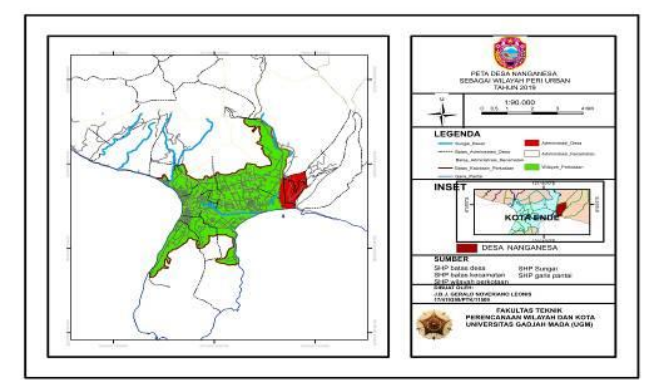

Gambar 1. Peta Letak Desa Nanganesa

\section{Teori pilihan Rasional}

Dalam pada itu, yang mesti dilihat lebih jauh adalah motivasi masyarakat setempat menjual tanah. Dalam usaha melihat sebuah problem makro, maka yang perlu dilakukan adalah bagaimana kita mendalami masalah mikro. Kajian dalam hal mikro, merupakan pijakan awal untuk melihat problem makro secara lebih komprehensif.

Coleman sendiri merupakan analis individualis yang mencermati secara khusus metode individualis dengan fokus utama pada kemungkinan - kemungkinan internal yang terjadi dalam level mikro. Baginya, gagasan dasar yang dimiliki adalah; "orang-orang bertindak secara sengaja kea rah suatu tujuan, dengan tujuan itu dibentuk oleh nilai-nilai ataupun pilihan-pilihan” (Coleman:1990). Pertimbangan paling rasional sebuah keputusan tercetak dalam tindakantindakan aktor didominasi oleh faktor ekonomi. Perilaku seperti ini dilakukan untuk memaksimalka manfaat-manfaat, keuntungan serta pemuasan kebutuhankebutuhan behaviourists. Adapun unsur yang menjadi titik sentral dalam teori dan mesti ada adalah Aktor dan sumber daya. Tentu saja dalam konteks ini Aktor memiliki keleluasan dalam mengendailkan sumber daya yang dimilikinya. Dan interaksi yang terjadi antar actor dengan sumber dayanya dalam sebuah proses interrelasi dalam sebuah unit sistem, tentu dapat menjadi rujukan untk lebih memahami hubungan isu mikro dan makro (Ritzer, 2012).

Maka dari itu, penelitian ini akan coba mengurai motif apa saja yang melatarbelakangi masyarakat menjual lahan. Karena lebih lanjut akan terungkap seberapa pengaruh keputusan rasional masyarakat ini dengan perubahan wajah desa serta efeknya terhadap sendi-sendi sosial, ekonomi dan fisik Desa yang selama ini dihidupi dengan baik.

\section{METODE PENELITIAN}

Penelitian ini menggunakan metode kualitatif yaitu prosedur penelitian yang 
menghasikan data gambaran akan hal yang terucap secara lisan ataupun dengan hal hal tertulis dari orang-orang dan perilaku orang yang diamati (Maleong:2006). Penelitian ini menggunakan pendekatan studi kasus eksplanasi yang bertujuan untuk menjelaskan motif masyarakat menjual tanah dan dampak yang diakibatkan bagi masyarakat itu sendiri dan Desa secara umum.

Lebih lanjut penelitian ini dilakukan di Desa Nanganesa, Kabupaten Ende. Sumber data dibedakan atas sumber data primer dan sumber data sekunder. Sumber data primer didapat dengan cara wawancara yang mendalam (in depth interview) terhadap para informan. Wawancara yang mendalam ini dengan menghubungi aparatur Desa Nanganesa, para penjual lahan, dan beberapa masyarakat desa yang mempunyai kapabilitas dan mengetahui secara pasti keadaan desa. Sementara sumber data sekunder berupa dokumentasi dan arsiparsip resmi yang dapat mendukung hasil penelitian. Untuk mendapat data sekunder, cara yang dilakukan adalah mengkaji dokumen desa yang berkaitan dengan penjualan tanah dan berbagai kebijakan desa dalam membangun desanya Di samping itu penulis melakukan observasi memperkuat hasil wawancara.

Dalam analisis data kualitatif, Studi Kasus dijadikan strategi. Strategi dimaksud berdasarkan kerangka kerja deskriptif dan proposisi teoritis. Analisis ini dibuat untuk mengantisipasi penelitian yang tidak memiliki proposisi empirik. Dan proposisi teoritis merupakan upaya perbandingan antara proposisi empirik dan data yang didapat di lapangan.
Penelitian ini menitikberatkan pada hubungan kasualitas dari ledakan penduduk di kota seketika menjadi dampak yang menyebabkan penduduk kota mencari lahan alternatif dengan wajah baru Desa akibat dari allihfungsi lahan. Dan untuk mendapatkan benang merahnya makanya penelitian ini menggunakan teknik eksplanasi. Teknik eksplanasi merujuk relasi pilihan rasional masyarakat menjual lahan dan pengaruh spasial, sosial dan ekonomi yang terjadi di dalamnya.

\section{HASIL DAN PEMBAHASAN}

Data mencatat jumlah penduduk di Desa Nanganesa berjumlah 535 KK (Data Desa, 2018). Umumnya penduduk setempat yang memiliki latar belakang Pendidikan di bawah Sekolah Menengah Atas (SMA). Namun kebanyakan dari memiliki luasan lahan yang besar karena merupakan warisan dari orang tua. Lahan itulah yang mereka gunakan sebagai sumber penghidupan dengan bertani. Walaupun dengan pendapatan yang tidak tetap, mereka tetap bertekun dengan usahanya sebagai petani.

Di saat bersamaan, permintaan lahan yang tinggi untuk hunian dan pemukiman dari penduduk kota menjadi semakin massif. Dari sini lah transformasi wajah Desa Nanganesa bermula. Dengan munculnya calo-calo tanah yang kemudian menawarkan luas tanah dengan harga terjangkau kemudian menarik banyak pendatang bersedia membeli tanah di Desa Nanganesa. Dengan cepat fakta dan desas desus penjualan tanah di Desa Nanganesa menjadi konsumsi publik di Kota.

\section{Faktor-Faktor yang menyebabkan penjualan lahan.}


Ada banyak argumentasi yang melatar belakangi aksi penduduk desa Nanganesa menjual lahan. Namun penulis merangkumnya dalam 4 (empat) dimensi sebagai motif paling dominan. Pertama, Dimensi Ekonomi. Kenyataan bahwa kebutuhan yang semakin meningkat yang tidak disertai dengan pendapatan tetap memberikan impuls bagi penduduk desa Nanganesa untuk menjual lahanya. Tuntutan ekonomi bagi keluarga, ditambah begitu banyak pembeli bersedia membayar tunai lahan yang dijual membuat masayarakat bersedia segera menjual tanahnya. Kedua, Dimensi sosial. Perkembangan zaman kemudian menggeser lifestyle dalam berelasi sosial. Penduduk Desa Nanganesa kemudian semakin berubah dalam cara berpakaian, berkehidupan sosial dengan membangun rumah semipermanen/permanen dan mulai memiliki kendaraan bermotor, entah roda dua maupaun roda empat hasil dari menjual tanah. Ketiga, Dimensi Psikologis. Hal inilah yang kerap ditemukan adalah keputusan menjual tanah adalah untuk memenuhi kepuasan dalam diri agar mampu mengimbangi kemapanan penduduk kota yang bermukim disekitar. Keempat Dimensi Kultural. Tak dapat diingkari bahwa masyarakat Desa memiliki keterkaitan kuat dengan adat budaya. Mengapa dimensi budaya menjadi motif penjualan tanah? Hal ini dikarenakan dalam adat budaya Ende Lio, dalam prosesi tertentu biasanya membutuhkan biaya yang tidak sedikit. Ambil satu contoh untuk detail. Dalam acara pernikahan, sebelum pernikahan berlangsung ada prosesi antar belis. Hal ini dimaknai sebagai penghargaan akan eksistensi seorang perempuandalam budaya. Materi belis merupakan kombinasi dari hewan dan uang. Dan dalam jumlah yang tidak sedikit. Untuk memenuhi itu semua, maka pihak keluarga mengadakan urun rembug yang dalam terminologi bahasa setempat disebut wurumana. Hal ini bertujuan unutk mengajak setiap anggota keluarga berkontribusi dalam bentuk uang atau hewan demi menyukseskan acara lamaran tersebut. Dalam hukum adat, hal ini merupakan ritual wajib dan mengikat. Sekalipun tidak tertulis dalam aturan, namun setiap orang yang memahami adat akan dengan sepenuhnya mematuhi aturan berlaku tanpa pernah mengeluhkan nominal kontribusi yang dibebankan. Dengan keadaan seperti ini bagi masyarakat Desa Nanganesa menjadi alasan mereka menjual lahannya. Karena lahan merupakan cara pintas mendapatkan uang dalam waktu singkat dan cepat.

\section{Dampak Penjualan Lahan}

Beberapa motif yang melatarbelakangi keputusan menjual lahan bagi penduduk kota memberikan implikasi yang besar bagi perubahan wajah desa. Implikasi yang terjadi juga dilihat dari berbagai aspek:

Secara fisik Desa Nanganesa mengalami distorsi. Daerah pertanian akhirnya terkonversi menjadi pemukiman dan industri dan jasa. Mari kita lihat perkembangan desa dengan periode waktu berikut:

\begin{tabular}{|c|c|c|}
\hline Peta Guna & Peta Guna \\
\hline Peta Guna & Pahan Desa \\
Lahan Desa & Lahan Desa \\
Nanganesa & Nanganesa & Nanganesa \\
2003 & 2013 & 2018 \\
\hline
\end{tabular}


Gambar 2. Peta Guna Lahan Desa Nanganesa Tahun 2003, 2013, dan 2018

\begin{tabular}{llccc}
\hline NO & $\begin{array}{l}\text { Penggunaan } \\
\text { Lahan }\end{array}$ & $\begin{array}{c}\text { Tahun } \\
2003\end{array}$ & $\begin{array}{c}\text { Tahun } \\
2013\end{array}$ & $\begin{array}{c}\text { Tahun } \\
2018\end{array}$ \\
\hline 1 & Pemukiman & $30 \mathrm{Ha}$ & $31 \mathrm{Ha}$ & $37 \mathrm{Ha}$ \\
\hline 2 & Pertanian & $24 \mathrm{Ha}$ & $15 \mathrm{Ha}$ & $13 \mathrm{Ha}$ \\
& sawah & & & \\
\hline 3 & Perkebunan & $91 \mathrm{Ha}$ & $80 \mathrm{Ha}$ & $70 \mathrm{Ha}$ \\
& Campur & & & \\
& & & & \\
\end{tabular}

\section{Tabel 1. Tabel penggunaan lahan di} Desa Nanganesa

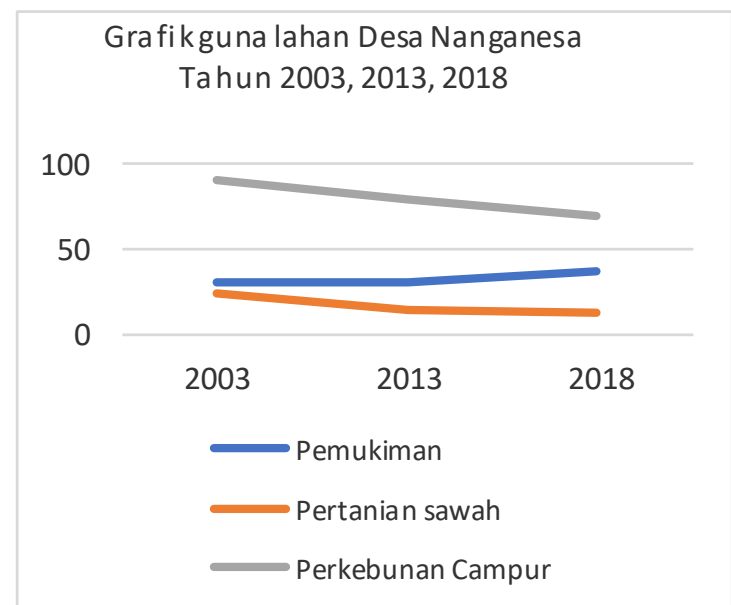

Gambar 3. Grafik guna Lahan di Desa Nanganesa

Dari peta tampakan, tabulasi, dan grafik penggunaan lahan di atas, tergambar jelas bahwa telah terjadi perubahan alihfungsi lahan yang sangat signifikan.

Dari tahun 2003 ke tahun 2013 hingga tahun 2018 menunjukkan tren menurun pada lahan pertanian sawah dan perkebunan campur, namun sebaliknya dalam periode waktu yang sama tingkat kenaikan yang pasti terjadi pada hunian atau pemukiman.

Deskripsi singkat ini menunjukkan beberapa hal yang mesti dicermati:

1. Aspek Fisik, dengan ekspansifnya dan masifnya pendatang dengan keinginan menetap serta membangun hunian baru yang elitis dan modern, mengisyratkan perlunya kepekaan Pemerintah Desa sebagai lembaga yang paling berwenang menata dan mengelola Desa untuk membangun infrastruktur merujuk amanah dari Undang-Undang nomor 6 Tahun 2014 tentang Desa. Hal ini perlu karena merupakan usaha preventif Desa agar mencegah terjadi urban sprawl, serta perlunya menjaga keasrian desa dalam relasi sosial dengan menjangkau seluruh masyarakat tanpa terkecuali. Dalam konteks demikian Pemerintah Desa berinisiatif membangun jaringan jalan, serta infrastruktur lainnya demi pemenuhan kebutuhan masyarakat desa. Tidak hanya disitu, karena eloknya desa Nanganesa sebagai tujuan alternatif pembangunan hunian baru, tidak heran banyak sekali pembangunan hunian ataupun pabrik dan PUB. Kesempatan untuk berubah memberikan keleluasaan untuk bergerak bersama modernitas.

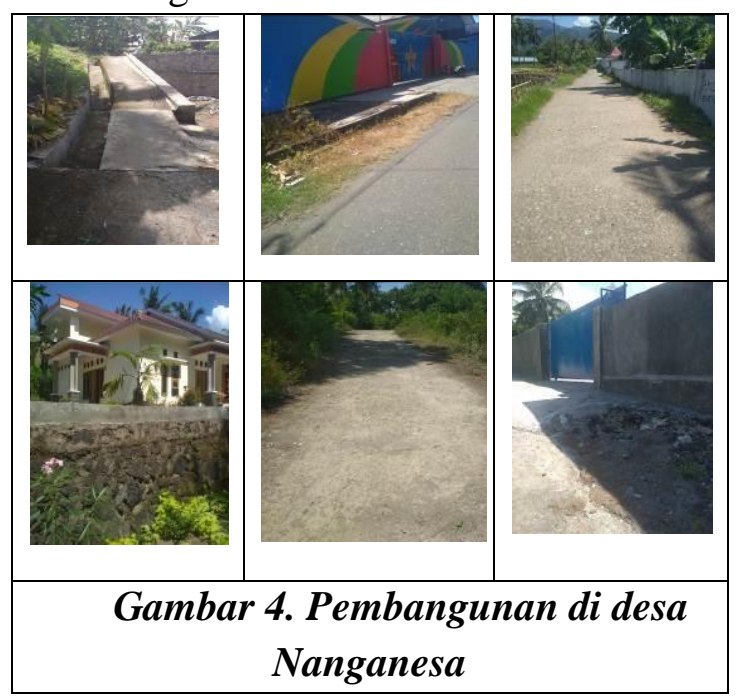

2.Aspek Sosial. Bersamaan dengan terjadinya transformasi spasial, aspek yang lain secara simultan pun ikut terpengaruh. Ketika pendatang/pemukim kota membangun rumah yang permanen dan modern serta berdampingan dengan 
masyarakat tradisional, maka yang terjadi akan adalah pandangan akan kesenjangan. Dari kondisi demikian sangat berpotensi mengganggu ikatan kuat masyarakat Desa Nanganesa. Iklim sosial tradisional mendapat tantangannya tersendiri.

Tidak hanya itu dengan bermukimnya penduduk kota dengan latar belakang Pendidikan yang baik, kemapanan secara ekonomi serta pola pikir yang modern ini pada dasarnya memberikan tabrakan cara pandangan pada dua kategori masyarakat ini.

Merujuk pada pandangan Inkels dalam Harsojo yang mencirikan manusia modern dapat menjadi representasi penduduk/pemukim baru di Desa Nanganesa ke dalam beberapa ciri dan paradoksnya dengan masyarakat tradisional/setempat diantaranya; mereka (pemukim baru) sangat inovatif dan terbuka terhadap setiap inchi perubahan yang terjadi. Lain halnya dengan masyarakat tradisonil desa yang cenderung pasif terhadap ide baru serta perubahan dan cara baru yang berkembang. Pemukim baru lebih update dan peka terhadap kejadian dalam lingkungan maupun di luar ligkungannya dan invander giat dalam menyikapi setiap situasi yang terjadi dengan ditunjukkan dalam opini maupun disposisi hati. Berbeda dengan manusia modern, masyarakat desa tidak terlalu care dan aware dalam melihat situasi karena bagi mereka hal ini mesti dan selayaknya terjadi.

Ciri lain para pendatang dari kota adalah betul-betul memanfaatkan setiap detik waktu. Hal ini dapat dilihat dengan tekunnya mereka memanfaatkan waktu karena bagi mereka orientasi hidup mesti untuk hari ini dan masa yang akan datang. Orang dengan ciri modern begitu menghargai waktu, dan pengaturan waktu dengan rinci, jelas dan tegas. Segala sesuatu disusun dengan baik dan seturut rencana kerja berdasarkan alokasi waktu yang terukur. Lain halnya dengan masuyarkat tradisonil yang memiliki kesan menghabiskan waktu untuk hal-hal yang bersifat profan. Pemukim desa yang baru mempertegas penghargaan waktu ini dengan memiliki perencanaan hidup dan sangat fasih dalam mengorganisasi dan mengatur hidupnya. Jelas ini sangat paradox dengan masyarakat desa yang memiliki tendensi minimnya penataan diri dan hidup secara umum.

Penduduk yang datang dari kota biasanya sangat mempercayai ilmu dan teknologi. Sedangkan masyarakat desa berpegang teguh pada tradisi dan unsr adat di dalamnya.

Dalam sebuah unit seperti desa dimana bermukim penduduk desa dan masyarakat pendatang yang memiliki cri moernitas dalam pikir dan hidupnya, akan tampak sebuah model relasi yang bertolak belakang. Hal ini dapat dilihat dari derajat rasionalitas yang dirpeankan dalam setiap tindakannya. Masyarakat yang beraroma kota selalu melakukan kegiatan berdasarkan nilia dan pola-pola objektif serta sangat efektif. Dalam pada itu, masyarkat ini melihat ilmu dan tekonolgi sebagai kekuatan yang mendorong untuk bekerja dan bertingkah laku. Hal yang jauh berbeda dilakukan oleh masyarakat desa, tingkat sentimental yang tinggi, primordialisme, sangat familiar dengan hal-hal yang berbau seremonial dan tradisional.

Dalam konteks Desa Nanganesa, Begitu ekspansifnya penduduk kota dengan berbagai latar belakang dan ciri yang digambarkan di atas, diyakini mampu 
menggeser sendi-sendi sosial lama dan sudah fasih dihidupi. Secara sosiologis, relasi sosial dalam rupa gotong royong dan kebersamaan berangsur-angsur berubah menjadi lebih individualistik. Hal ini dipengaruhi karena tabrakan pola pikir antara masyarakat tradisional yang homogen dan kerap hidup berkumpul disandingkan masyarakat kota yang lebih suka menghabiskan waktu untuk bekerja, dan setiap waktu luang dihabiskan dengan keluarga dan rekreasi.

Hal ini tidak berarti diantara mereka tidak berelasi/berkomuniksi sama sekali namun kohesivitas sosial yang dihidupi tidak sekuat dulu. Pemukim kota secara sadar atau tidak, mempengaruhi perspektif sosial masyarakat setempat. Tidak ada gunanya menghabiskan waktu hanya untuk berkumpul bahas hal yang tidak ada faedahnya bagi diri, keluarga dan masyarakat.

Ketika setiap orang menyibukkan diri sendiri, maka konteks soliditas kohesivitas sosial menemukan racunnya. Dengan tampilan pola kehidupan yang individualistik, ignorance, dan enggannya/mandeknya partisipasi aktif dalam kegiatan bersama masyarakat akan sulit bagi kita untuk menemukan para bapak yang duduk sore bersama bersenda gurau menghabiskan waktu membicarakan banyak hal, atau anak-anak muda yang nongkrong di rumah teman untuk belajar bersama. Dekohesivitas sosial telah melanda Desa Nanganesa.

Hal lain yang secara sosilogis dapat dilihat lebih jauh adalah soal citra yang dibangun dalam pandangan masyarakat kota Ende. Banyak perspektif yang cukup nyeleneh saat membicarakan soal Desa Nanganesa. Bagi mereka image yang tercipta adalah Desa Nanganesa merupaka surge PUB and Karaoke. Dan secara sosiologis hal ini membangun gambaran yang kurang elok bagi masyarakat Desa.

\section{Aspek Ekonomi.}

Perubahan Fisik dengan munculnya hunian baru. Masyarakat dipaksa adaptif dalam menemukan pekerjaan baru demi pemenuhan kebutuhan keluarga. Lahan yang menjadi sumber pendapatan dengan usaha bertani sudah dijual.

Potensi implikasi ekonomi yang terjadi adalah dengan peralihan pekerjaan pokok. Hal ini terlihat ketika mereka bekerja sebagai buruh pabrik yang berada di situ atau dengan menjadi security di PUB dan Gudang-gudang yang dibangun di bekas lahan mereka. Masyarakat perlu memanfaatkan segala akses yang mampu menambah penghasilan bagi kebutuhan keluarga. Bagi penulis, hal ini merupakan keputusan paling rasional yang dibuat demi merawat pendapatan agar kebutuhan ekonomi keluarga tetap terjaga.

Sebuah pilihan paling rasional di tengah gencarnya brand wilayah PUB dan Karaoke yang melekat. Terkesan kurang positif namun di sisi lain memberikan lapangan kerja bagi masyarakat sekitar.

Lebih jauh lagi. ketika menyadari bahwa sumber daya lahan yang dimiliki sudah tidak ada, masyarakat desa mulai proaktif untuk segera mencari kegiatan baru yang menghasilkan. Untungnya dalam kondisi ini, peran aparatur desa begitu krusial. Sebagaimana dilihat dari kondisi nyata di desa, pelibatan aktif masyarakat desa dalam setiap pembangunan desa yang menggunakan dana desa sungguh menjadi profesi baru yang mampu membantu ekonomi keluarga. 


\section{Aspek Kultural}

Irisan terjadi dalam aspek kultural ini menjadi lebih luas ketika akibat dari relasi sosial yang terjadi antar pemukim setempat dan pendatang, telah membidani lahirnya cara pandang lain terhadap adat dan budaya yang berlaku. Misalnya ketika kebutuhan akan adat dan budaya sebagai faktor yang memengaruhi penjualan tanah sebagai pemenuhan kontributif antar anggota keluarga demi meluluskan prosesi lamaran hingga pernikahan akan dianggap sebagai hal yang tidak mesti dilakukan lagi. Cara pandang demikian muncul berkaitan dengan menurunnya kenyamanan ekonomi yang dialami masyarakat. Pandangan terhadap aturan yang selama ini mengikat berubah menjadi cara pandang yang membebani. Aturan adat tentang sumbangsih terlihat terbebani. Perspektif demikian menjadi bukti semakin berubahnya wajah desa.

\section{SIMPULAN}

Alihfungsi Lahan berdampak ganda dalam perkembangan desa. Wajah Desa berubah menarik dengan pembangunan infrastruktur dan serta bangunan hunian semi/modern. Konversi lahan juga memacu meningkatkan percepatan pembangunan fisik dan pola pikir manusia desa. Sebagaimana Phil Astrid (1983) mengungkapkan sebuah proses modernisasi merupakan kesempatan yang diberikan masa perubahan demi kemajuan.

Perubahan merupakan dinamika yang selalu dan akan terjadi. Perubahan menimbulkan kemajuan yang dapat berdampak positif ataupun negatif.
Positifnya adalah wajah Desa Nanganesa semakin berbenah, pembangunan infrastruktur kian gencar dan kemajuan desa kian pesat dengan banyaknya sarana dan prasarana yang lengkap dan menunjang mobilitas dan kebutuhan masyarakat. Di sisi lain, negatifnya adalah Desa Nanganesa merupakan desa yang harmoni, dengan segala keunikannya, desa Nanganesa dan beserta masyarakatnya berubah bersama dengan masa. Sudah tidak terlalu banyak lagi petak-petak sawah yang ada, perkebunan ladang sudah berubah muka menjadi hunian rumah yang elit dan tak lagi ramah, pabrik serta bangunan bernuansa modern semakin menancapkan eksistensinya.

Tidak hanya tubuh desa Nanganesa yang berubah, jiwa dalam konfigurasi nilai dan sistem sosial, ekonomi dan budaya yang selama ini dihidupi kian pudar. Wujud kebersamaan, gotong royong dan saling bercengkrama dalam ceria telah berganti dengan wajah penuh aktif dan efektif.

Desa Nanganesa merupakan model bahwa masifnya penjualan tanah, telah merubah wajah desa menjadi wajah kekotaan. Di samping terbentuk citra negatif namun paling tidak, tingkat adaptasi masyarakat dengan keadaan yang "baru" telah cukup membuat kelabakan masyarakat setempat. Masyarakat dituntut untuk menyesuaikan pola pikir dan perilaku yang sebenarnya "awam" bagi mereka. Demikian cara yang paling rasional harus dilakukan agar bisa survive dalam setiap laju perubahan zaman. 


\section{DAFTAR PUSTAKA}

Adisasmita, Rahardjo, (2010), Pembangunan Pedesaan dan Perkotaan, Yogyakarta; Graha ilmu.

Coleman, James S. (1990), Foundation of Social Theory, Cambridge, MA: Harvard University Press

George Ritzer. (2012), Teori Sosiologi, Penerbit Pustaka Pelajar. Yogyakarta

Harsojo, (1984), Pengantar Antropologi, Jakarta: Binacipta

Leibo, Jefta. Sosiologi Pedesaan (Mencari Sebuah Strategi Pembangunan Berparadigma Ganda). Yogyakarta: Andi Offset

Moeolong, J. Lexy. (2009), Metode Penelitian Kualitatif. PT. Remaja Posdakaya, Jakarta

Phil Astrid, S. Susanto, (1983), Pengantar Sosiologi dan Perubahan Sosial. Jakarta; Bina Cipta

Susan, Novri M.A. (2009). Sosiologi Konflik Dan Isu-Isu Konflik Kontemporer, Jakarta: Kencana Prenada Media Group.

Yin. R.K. (2011). Studi Kasus: Desain dan Metode, Penerbit Rajawali Press. Jakarta

Undang- Undang Nomor 6 Tahun 2014 Tentang Desa 